\title{
Effect of Packaging Materials and Temperature on Post-harvest Life of Gladiouls cv. Punjab Dawn
}

\author{
Anjana Sisodia*, Priyanka Kumawat, Minakshi Padhi and Anil K. Singh \\ Department of Horticulture, Institute of Agricultural Sciences, \\ Banaras Hindu University, Varanasi-221005, U.P., India \\ *Corresponding author
}

A B S T R A C T

\begin{tabular}{|l|}
\hline Ke y w o r d s \\
Gladiolus, \\
Packaging \\
materials, \\
Temperature, Post- \\
harvest life
\end{tabular}

\section{Keywords}

\section{Introduction}

Gladiolus is a high value crop among cut flowers. The fascinating spikes bear a large number of florets with varying sizes and forms with smooth ruffled or crinkled tepals (Singh, 2006). Storage extends the marketing season and regulates marketing in times of glut production. Appropriate method of storing flowers offers the possibility of long term shipment (Jain et al., 2006). Cut flower longevity depends on the carbohydrate reserves of flowers, osmotic concentrations and pressure potential of petal cells, stomatal

\begin{abstract}
An experiment was conducted to study the effect of temperature and different packaging materials on post-harvest life of gladiolus spike at Post-harvest Laboratory, Department of Horticulture, Institute of Agricultural Sciences, Banaras Hindu University, Varanasi, during the year 2017. Experiment was laid out in Completely Randomized Design with three replications. The results revealed that gladiolus spike stored at $16^{\circ} \mathrm{C}$ (cool chamber condition) and $22 \pm 2^{\circ} \mathrm{C}$ (ambient condition) failed to exert any significant effect on days to open of third and fifth floret, percentage of opened florets, diameter of fifth floret and length of fifth floret. Maximum diameter, days to withering of first and third florets, weight of spike at third, sixth and ninth day and shelf life was recorded with cellophane paper packaging. There was no any significant difference between ambient $\left(22 \pm 2^{\circ} \mathrm{C}\right)$ and cool chamber condition $\left(16^{\circ} \mathrm{C}\right)$ on weight of spike at third, sixth and ninth day, days to withering of first and third floret and shelf life of spike. Whereas, maximum length of first floret was observed with spike packed in news paper. Spikes stored in cool chamber resulted in maximum days to withering of fifth floret.
\end{abstract}

functioning, variation in stem diameter and rigidity, differences in the number of thick walled supporting cells in the xylem elements and phloem fiber, lignifications and level of plant hormones and vulnerability of diseases and pests (Bhattacharjee, 1999). Use of packaging materials increases the vase life of flowers. Different type of packaging materials can be used to extend the shelf life of flowers $v i z$. news paper, butter paper, cellophane paper, plastic bags, CFBoxes, etc. which help in slow opening of florets. They reduce the amount of production of $\mathrm{O}_{2}$ and increase the production of $\mathrm{CO}_{2}$. This mechanism checks 
the metabolic process of flowers which prolongs the shelf life of flowers. Low temperature helps in reducing the amount of ethylene, which is responsible for quality improvement and increase storage life of gladiolus spikes. Cut spikes of gladiolus do not store well under refrigerated condition for long duration. The spike could also be stored under controlled atmosphere (CA) storage in poly propylene sleeves with $2 \%$ and $5 \% \mathrm{O}_{2}$ and $\mathrm{CO}_{2}$, respectively for about 15 days (Singh, 2006). Therefore, an experiment was conducted to study the effect of various packaging materials and different temperature on post-harvest life of cut gladiolus spikes cv. Punjab Dawn.

\section{Materials and Methods}

The corms of gladiolus cv. Punjab Dawn were raised at Horticulture Research Farm, Institute of Agricultural Sciences, Banaras Hindu University, Varanasi, Uttar Pradesh following standard cultural practices. The experiment was carried out in the Post-harvest Laboratory, Department of Horticulture during the year 2017. Spikes were harvested in early morning when three lower florets show colour.

A slant cut was given with the help of a sharp knife as close to the base. After harvesting, cut spikes were kept in a bucket containing water and immediately brought to the laboratory for post-harvest studies. All the leaves were removed and again a cut was given to the spikes with the help of a sharp knife. Standard length of spike was maintained. After weighing fresh weight and measuring length of spikes, the spikes were kept in envelops of different packaging materials viz., blotting paper, brown paper, butter paper, cellophane paper and news paper. Envelops were put in cardboard boxes and placed at different temperature conditions. Observations were recorded on various post-harvest attributes and data were analyzed statistically.

\section{Results and Discussion}

Gladiolus spike stored at $16^{\circ} \mathrm{C}$ (cool chamber condition) and $22 \pm 2^{\circ} \mathrm{C}$ (ambient condition) failed to exert any significant effect on days to open of third and fifth floret, percentage of opened florets, diameter of fifth floret and length of fifth floret. However, significantly slow opening was observed under cool chamber condition $\left(16^{\circ} \mathrm{C}\right)$. Similarly, lesser diameter of first and third floret was observed under cool chamber condition $\left(22 \pm 2^{\circ} \mathrm{C}\right)$. Low temperature helps to reduce the amount of ethylene and decrease the rate of respiration, which is responsible for flower opening. Therefore, rate of opening of florets was found slow in cool chamber condition $\left(16^{\circ} \mathrm{C}\right)$. Beura and Singh (2003) and Grover et al., (2005) were also found same results. Various packaging materials failed to give any pronounce effect on days to fifth floret opening, percentage of opened floret, diameter of fifth floret and length of third and fifth floret. However, there was significant effect of different characters due to various packaging materials (Table 1). Late opening of first floret was observed with news paper, brown paper, butter paper and even control in comparison to cellophane paper. However, third floret was opened late in the spike packed in brown paper followed by news paper. Fast opening of third floret and maximum diameter of first and third florets were observed in cellophane paper packaging. However, it was significantly minimum with packaging of spikes in brown paper. Maximum length of first floret was observed with spike packed in news paper which was significant to packaging of spike in butter paper. This might be due to the wrapping with polypropylene sheet, makes the microenvironment become rich in $\mathrm{CO}_{2}$ with less $\mathrm{O}_{2}$, thus might have reduced the rate of respiration as well as inhibiting ethylene action (Munsi et al., 2011). 
Table.1 Effect of temperature and packaging materials on days to opening of floret, percent of opened florets, diameter of floret and length of floret in post-harvest life of gladiolus cultivar Punjab Dawn

\begin{tabular}{|c|c|c|c|c|c|c|c|c|c|c|}
\hline \multirow[t]{2}{*}{ Temperature } & \multicolumn{3}{|c|}{ Days to opening of floret } & \multirow{2}{*}{$\begin{array}{c}\text { \%of } \\
\text { opened } \\
\text { florets }\end{array}$} & \multicolumn{3}{|c|}{ Diameter of floret $(\mathrm{cm})$} & \multicolumn{3}{|c|}{ Length of floret $(\mathrm{cm})$} \\
\hline & $\begin{array}{l}\text { First } \\
\text { floret }\end{array}$ & $\begin{array}{l}\text { Third } \\
\text { floret }\end{array}$ & $\begin{array}{l}\text { Fifth } \\
\text { floret }\end{array}$ & & $\begin{array}{c}\text { First } \\
\text { floret }\end{array}$ & $\begin{array}{l}\text { Third } \\
\text { floret }\end{array}$ & $\begin{array}{l}\text { Fifth } \\
\text { floret }\end{array}$ & $\begin{array}{l}\text { First } \\
\text { floret }\end{array}$ & $\begin{array}{l}\text { Third } \\
\text { floret }\end{array}$ & $\begin{array}{l}\text { Fifth } \\
\text { floret }\end{array}$ \\
\hline Ambient condition $\left(22 \pm 2^{\circ} \mathrm{C}\right)$ & 3.50 & 4.44 & 4.11 & 46.89 & 6.74 & 7.02 & 4.82 & 8.08 & 7.43 & 5.08 \\
\hline Cool chamber condition $\left(16^{\circ} \mathrm{C}\right)$ & 3.11 & 4.33 & 5.22 & 45.96 & 6.26 & 6.19 & 5.26 & 7.37 & 6.28 & 5.98 \\
\hline CD at $5 \%$ & 0.36 & NS & NS & NS & 0.29 & 0.28 & NS & 0.52 & 0.46 & NS \\
\hline \multicolumn{11}{|l|}{ Packaging material } \\
\hline Control & 3.50 & 4.33 & 4.67 & 44.48 & 6.45 & 6.58 & 5.08 & 8.10 & 6.40 & 5.12 \\
\hline Blotting paper & 3.33 & 4.17 & 4.50 & 51.65 & 6.57 & 6.73 & 5.53 & 7.87 & 7.10 & 6.17 \\
\hline Brown paper & 3.50 & 5.50 & 5.83 & 40.81 & 5.97 & 6.17 & 4.87 & 7.40 & 7.48 & 5.77 \\
\hline Butter paper & 3.50 & 4.17 & 4.17 & 45.38 & 6.73 & 6.68 & 4.18 & 6.50 & 6.50 & 4.25 \\
\hline Cellophane paper & 2.50 & 3.50 & 4.17 & 50.21 & 7.17 & 7.25 & 6.50 & 8.18 & 6.55 & 7.02 \\
\hline News paper & 3.50 & 4.67 & 4.67 & 46.03 & 6.10 & 6.23 & 4.05 & 8.30 & 7.10 & 4.85 \\
\hline CD at $5 \%$ & 0.63 & 0.89 & NS & NS & 0.51 & 0.48 & NS & 0.89 & NS & NS \\
\hline
\end{tabular}

Table.2 Effect of temperature and packaging materials on weight of spike, days to withering of floret and shelf life in post-harvest life of gladiolus cultivar Punjab Dawn

\begin{tabular}{|c|c|c|c|c|c|c|c|}
\hline & \multicolumn{3}{|c|}{ Weight of spike (g) } & \multicolumn{3}{|c|}{ Days to withering of floret } & \multirow{2}{*}{$\begin{array}{c}\text { Shelf life } \\
\text { (days) }\end{array}$} \\
\hline & $\begin{array}{c}\text { Third } \\
\text { day }\end{array}$ & Sixth day & $\begin{array}{c}\text { Ninth } \\
\text { day }\end{array}$ & $\begin{array}{l}\text { First } \\
\text { floret }\end{array}$ & $\begin{array}{l}\text { Third } \\
\text { floret }\end{array}$ & $\begin{array}{l}\text { Fifth } \\
\text { floret }\end{array}$ & \\
\hline \multicolumn{8}{|l|}{ Temperature } \\
\hline Ambient condition $\left(22 \pm 2^{\circ} \mathrm{C}\right)$ & 32.44 & 29.52 & 25.48 & 2.83 & 4.33 & 2.83 & 8.22 \\
\hline Cool chamber condition $\left(16^{\circ} \mathrm{C}\right)$ & 33.17 & 30.68 & 26.66 & 3.00 & 4.56 & 4.28 & 8.44 \\
\hline CD at $5 \%$ & NS & NS & NS & NS & NS & 1.27 & NS \\
\hline \multicolumn{8}{|l|}{ Packaging material } \\
\hline Control & 32.18 & 28.32 & 21.76 & 2.50 & 3.83 & 3.83 & 6.83 \\
\hline Blotting paper & 31.77 & 28.63 & 25.10 & 2.50 & 4.17 & 4.17 & 8.33 \\
\hline Brown paper & 33.32 & 30.78 & 26.04 & 2.17 & 4.50 & 3.00 & 8.33 \\
\hline Butter paper & 29.74 & 26.46 & 21.94 & 3.17 & 4.83 & 2.50 & 8.33 \\
\hline Cellophane paper & 37.29 & 36.74 & 36.16 & 4.17 & 5.83 & 5.50 & 9.17 \\
\hline News paper & 32.53 & 29.69 & 25.41 & 3.00 & 3.50 & 2.33 & 9.00 \\
\hline CD at $5 \%$ & 4.30 & 4.00 & 3.72 & 0.92 & 1.41 & NS & 0.98 \\
\hline
\end{tabular}


Similar result was lent credence with the finding of Reddy (2016) in tuberose. There was no any significant difference between ambient $\left(22 \pm 2^{\circ} \mathrm{C}\right)$ and cool chamber condition $\left(16^{\circ} \mathrm{C}\right)$ on weight of spike at third, sixth and ninth day, days to withering of first and third floret and shelf life of spike. However, spikes stored in cool chamber resulted in maximum days to withering of fifth floret which was significantly higher than ambient condition.

Maximum weight of spike at third, sixth and ninth day was observed with spikes stored in cellophane paper followed by brown paper and news paper treatments. Significantly lower weight of spike was recorded with control condition. Maximum days taken to withering of first floret were recorded with spikes placed in cellophane paper which was statistically higher than other packaging materials. Similarly, maximum days taken to withering of third floret were recorded with cellophane paper which was statistically at par with butter paper and brown paper treatments and significant to news paper, blotting paper and control. Cellophane paper treatment was also resulted in longest shelf life of spikes, found significantly higher than control, which was at par with other treatments and significant to control. In cellophane paper there is no source of air motion therefore, reduction in weight of spike observed low due to low rate of respiration. Freshness of florets remain for longer duration due to less water loss from cellophane paper packed spike, therefore, withering of floret takes longer duration in spikes packed with cellophane paper. Cellophane paper packed spikes at low temperature condition was found significant. Palanikumar and Bhattacharjee (2001), Zeltzer et al., (2001), Naz (2003), Jain (2006) and Ahmad et al., (2013) were found similar results in rose.

\section{References}

Ahmad, I., Dole, J.M., Saleem, M., Khan, M.A., Akram, A. and Khan, A.S. (2013). Preservatives and packaging material have an impact on the postharvest longevity of cut Rosa hybrida L. Kardinal flowers. The Journal of Horticultural Science and Biotechnology, 88(3): 251-256.

Beura, S. and Singh, R. (2003). Effect of storage temperature and wrapping material on post-harvest life of gladiolus cultivar Her Majesty. Journal of Ornamental Horticulture, 6(4): 322-327.

Bhattacharjee, S.K. (1999). Research on agrotechnology in roses at IARI, New Delhi. Indian Rose Annual, 15: 80-86.

Grover, J.K., Gupta, A.K., Singh, K. and Brar, J.S. (2005). Modified atmosphere packaging of cut flowers in polymeric films-suitable technology for India. Proce: International Conference on Plasticulture and Precision Farming. New Delhi, India, 17-21 November, p. 258.

Jain, R., Bhalla, R., Gupta, Y.C., Thakur, K.S. and Thakur, R. (2006). Effect of wrapping material and dry storage on postharvest quality of rose cv. First Red cut flowers. Journal of Ornamental Horticulture, 9(3): 192195.

Munsi, P., Chakrabarty, S. and Roychowdhury, N. (2011). Effect of storage conditions and packaging supplemented with different solutions (wet packing) on vase life of gladiolus. Acta Horticulturae, pp. 351-357.

Naz, S. (2003). Effect of different packing materials on the post-harvest life of rose. Journal of Research Science, 14(2): 187-192.

Palanikumar, S. and S.K. Bhattacharjee (2001). Effect of wet storage on post- 
harvest life and flower quality of cut roses. Journal of Ornamental Horticulture, 4(2): 87-90.

Reddy (2016). Effect of post-harvest dipping, packaging and storage temperatures on keeping quality of loose flowers of tuberose (Polianthes tuberosa L.). M.Sc. Thesis, College of Horticulture, Rajendranagar, Hyderabad Dr. Y.S.R. Horticultural University.
Singh A.K. (2006). Flower Crops: Cultivation and Management, New India Publishing Agency, New Delhi, India. p. 447.

Zeltzer, S., Meir, S. and Mayak, S. (2001). Modified atmosphere packaging (MAP) for long- term shipment of cut flowers. Acta Horticulturae, 553: 631634.

\section{How to cite this article:}

Anjana Sisodia, Priyanka Kumawat, Minakshi Padhi and Anil K. Singh. 2018. Effect of Packaging Materials and Temperature on Post-harvest Life of Gladiouls cv. Punjab Dawn. Int.J.Curr.Microbiol.App.Sci. 7(08): 889-893. doi: https://doi.org/10.20546/ijcmas.2018.708.101 